\title{
SOME QUESTIONS OF COMPARATIVE STUDY OF SPEECH STAMPS OF UZBEK LANGUAGE
}

\section{Gulnoza Muxtarovna Akhmedova}

Tashkent Medical Pediatric University

\begin{abstract}
This article discusses the importance of the role of the study of speech stamps, template sentence words and phraseological units in teaching the Uzbek language in schools and groups with the Russian language of instruction. In the textbooks, speech stamps are presented without translation into Russian, without explanation of in which speech situations it is necessary to use them, which was the basis for the conclusion that it is necessary to prepare a list of Uzbek speech stamps in the form of an UzbekRussian dictionary to provide students with this material.
\end{abstract}

Keywords: linguistics, culture, competence, intercultural communication, lexical difficulty.

\section{INTRODUCTION}

The study of hackneyed phrases, template words-sentences and phraseological units plays an important role in teaching Uzbek language in schools and groups with Russian as the language of study. These language phenomena are part of the content of training, they serve to form correct communication, taking into account the social and moral relations that have historically developed among the Uzbek people.

\section{LITERATURE REVIEW AND METHODOLOGY}

The most difficult language units are phraseological combinations (phraseological locutions, phraseological units). Phraseological combinations ("Ziyoratingiz qabul bo'lsin"," Murodingiz hosil bo'lsin " - "Let wishes come true", as U. P. Lafasov calls them, based on sources on linguistics, resemble speech stamps (typical phrases). According to the author, these units are inherent only in Dialogic speech [1; p.97]. It becomes clear that speech stamps (speech cliches, hackneyed phrases, typical phrases), being a teaching linguistic unit of dialogical speech, go back to phraseological units that serve to Express the meaning of desire. For example, the expression "Yo'lingiz bexatar bo'lsin" - "Have a good journey!" can be considered not only a speech stamp, since, according to U.P. Lafasov, it can be called a phraseological stamp. For the reason that phraseological clichés inherent in the dialogues, it is possible to consider them in the number of voice stamps (typical phrases). 
In our speech, there are a lot of such speech cliches (phraseological units) that Express the meaning of desire. For example, Sadag'ang ketay! - I will bow to you! I will be your servant! Girgittoning bo'lay! Literally: I will Surround you with my care like a spindle! Baraka topgur! - Let you have everything in abundance!

Certain part of hackneyed phrases is rarely used in oral speech, especially in the speech of young people. Hackneyed phrases are studied in the receptive plan, but the main set of them is introduced in the productive plan.

Hackneyed phrases can be divided into the following 2 groups: 1) hackneyed phrases peculiar to oral everyday speech, 2) hackneyed phrases related to book speech.

In the textbooks "O'zbek tili" ("The Uzbek language"), speech stamps are presented without translation into Russian, without commenting on what speech situations they should be used in. This circumstance was the basis for the conclusion that it is necessary to prepare a list of Uzbek speech stamps in the form of an UzbekRussian dictionary to provide students with this material. It is also considered a big problem which speech cliches can be covered and in which conversational topics.

The most difficult aspect of our research, i.e. the main problem is related to finding Russian equivalents of some speech patterns, template words and phraseological units of the Uzbek language.

In order to read sentences in the Uzbek language and understand their content, the translation technique is studied. At first, that is, before the stage when the translation technique is not yet being developed, the student performs actions for the literal translation of sentences into Russian in the order in which the words and word forms in the sentence are given. This translation sometimes forms a sequence of Russian words, from which it is impossible to understand the idea in some phrases or sentences, which causes inaccurate perception of the content. The scientific Methodist R.A.Yuldashev, based on control materials, gives the following erroneous translations of students as examples: ana u stolda - that one on the table (instead of on that table), beshinchi sinfda - fifth in the class (instead of in the fifth grade), maktab hovlisida school in the yard (instead of in the school yard) [2; p.128]. It details the reasons for the inaccuracy of the literal translation. In the examples given, what does not allow you to correctly formulate a thought is the declension of the word being defined in the phrase: the student first translates the definition in the nominative case into Russian, and then inserts the word being defined in the appropriate form - in the desired case. There are few speech stamps that can be translated literally from Uzbek into Russian. Most speech stamps that are translated verbatim differ from their equivalents in Russian either lexically or grammatically, or both lexically and grammatically. 


\section{RESULTS AND DISCUSSION}

This can be clearly seen by comparing the linguistic phenomena of both languages.

Uzbek hackneyed phrases, template words, and phraseological units are expressed in different ways in Russian:

1. These linguistic phenomena in both languages completely coincide with both the lexical and grammatical side and allow for literal translation. For example: Соғ бўлинг. - God bless you. Ишлар қалай? - What's up? Лаббай, эшитаман! - Hello, I'm listening! Майли! - Okay! Мархамат - Please. Иложи йўқ. - No opportunity.

In these examples, Uzbek words translated into Russian in the dictionary meaning are given in their own versions. For example: coғ - healthy; қалай - how; иш - work, affairs; эшитаман - I'm listening etc. The forms of words in both Uzbek and Russian are also the same: бўлинг - Be 1 healthy.

When translating Uzbek hackneyed phrases consisting of two or three words literally, their content can be understood even in the situation when the word order is changed. For example: Соғ бўлинг. -Be 1healthy. Ишлар қалай? - How things are Going? Энг яхши тилакларимни қабул этинг! - Please accept my best wishes! However, the student quickly realizes his mistake and puts the word order in accordance with the rules of Russian grammar.

2. Hackneyed phrases of Uzbek and Russian languages partially do not correspond to the lexical side. For example: Оқ йўл! -Have a safe journey! Хайрли тун! - Good night! айтганингиз келсин! - Let your wishes come true ... Ишларинг (ўқишларинг) яхшими? - How are you doing (studying)? Нима янгиликлар бор? What news (is there)? Яхшимисан, ўғлим? -Яхши юрибсанми? - How are you doing? Зарари йўқ! - Nothing wrong with that!

The dictionary meaning of the word оқ is white, and the word ëруғ is light, etc. But in the above examples the lexical meanings of words do not match: оқ (light), хайрли (calm), келсин (let them come true), яхшимисан (how are you), нима (which), юрибсанми (how are you), зарар (nothing).

The adjective яхши (good) in some Uzbek hackneyed phrases is translated into Russian by the word how (қандай). For example: Яхши юрибсанми? - How are you doing? Яхшимисан? - How are you? Соғлиқларинг яхшими? - How is your health? Ўқишларинг яхшими? - How was school? Ойинг яхшимилар? - How is (your) mother? In these translations, the word as in Russian is an interrogative word, good-an adjective. So, students should know that the word яхши in the Russian translation must be expressed by the word how, the lexical meaning of which in the Uzbek language is transmitted by the word қандай? 
Such translations mostly occur with hackneyed phrases in the form of an interrogative sentence. In narrative sentences expressing the meaning of desire, the word яхши is conveyed in its dictionary meaning (good), as well as in the way typical of the Russian hackneyed phrases, i.e., by different adjectives. For example: Яхши боринг: - Have a good trip! Яхши ётиб туринг. - Good night. Students make such transfers based on the wishes expressed by the interlocutors to each other.

However, in such translations, the Russian sentence does not Express the meaning of the wish, which is why the translation becomes erroneous. In such speech cliches as Яхши боринг (Have a good trip), Яхши ётиб туринг (Have a good sleep) to translate the literal meaning of the word яхши, you have to use the word Have, which addresses the lack of value wishes: have a nice trip, have a nice sleep.

In this case, the form of the Uzbek verb in Russian is expressed by a verbal noun. For example: Яхши боринг. - Нарру trip.

Some hackneyed phrases, template words, sentences, and phraseological units are also translated synonymously in Russian. But in Russian, if one of these synonyms is used actively, and the second and the rest are passive, then some are not used at all in speech. In this case it is impossible not to agree with the following statement of A.Juraev: "Cross-cultural communication requires the interlocutors to correctly apply language units not only in terms of language norms, but also their use in various speech situations within the culture of native speakers. This situation requires linguistic and cultural competence of foreign language teachers" [4;p.4]. For eхample: Хайрли тун! - Good night!

One of these translations (Good night!) it is considered active in the speech of native speakers. A teacher who is not aware of this may choose the second translation option and cause students to be confused. Although this translation is correct, it is not used in most cases.

In the following examples, the equivalent from the Russian language is selected for the Uzbek hackneyed phrases, resulting in a lexical discrepancy between the equivalents in both languages. For example: Зўр. - Great. Михдай. - On the dot. Йўқ, бўлмайди. - No, it won't work (it won't do, it won't fit). Жоним билан. - With pleasure (With kindness).

In the hackneyed phrases Михдай, the reason for the lexical discrepancy was the value approach to certain subjects of the Uzbek and Russian peoples. In Uzbek, a straight object, its good condition is compared to a nail (мих), and in Russian - with the bayonet of a machine gun.

Although hackneyed phrases, template words-sentences and phraseological units in Uzbek and Russian correspond from the grammatical side, the fact that some words 
are not reflected in the translation is the reason for discrepancies between them, so the literal translation is not complete. For example: Қийин бўлмаса. - If you don't mind. Мумкин бўлса. - If possible. Сиз ким бўласиз? - Who you are?

A word that is not expressed in Russian translation can create lexical difficulties. For example: Хўп, албатта, айтиб кўяман. - Okay, I will definitely pass it on (say). Йўқ, бошқа жойга тушиб қолдингиз. - No, you got to another number.

To translate into Russian such constructions with an auxiliary verb as деб қўяй (I will pass), айтиб кўяман (I will say), тушиб қолдингиз (you got), students put the main and auxiliary verbs in an indefinite form: деб (демоқ) - say, кўяй (кўймоқ) - to put, тушиб (тушмоқ) - to get, қолдингиз (қолмоқ) - to get, as a result, the meaning will be expressed incorrectly.

In this case, the teacher should ask students to translate only the main verb into Russian: деб (демоқ) - to say, айтиб (айтмоқ) - to say, тушиб (тушмоқ) - to get. As a result, it is possible to correctly Express hackneyed phrases in Russian and understand their content.

Some auxiliary verbs, in particular the verb куймоқ (to put), as part of constructions with auxiliary verbs are not reflected in the translation. For example: Салом, деб (айтиб) куй̆. - Say hello from me. In the translation of the verb Say the word кууй is not expressed.

In the Russian translation of some Uzbek hackneyed phrases, a word appears that is not present in the Uzbek version. For example: - Нима деб кўяй? - What should I tell him? Омадингиз келсин! - May good luck accompany You! Илтимос, кечир! - Please excuse me! Йўқ эдилар! - He (she) is gone! Овора бўлиб нима қилардинг? - There was no need (you) to bother.

In the above Uzbek hackneyed phrases (sentences), it is not necessary to use the words унга, сизнинг, сендан, у, узиингни, but in Russian it is necessary (mandatory) to use the words ему, Вам, тебя, его (ее), себя (him, You, you, him (her), yourself).

The student adds the missing word to avoid ambiguity in the translation of the sentence into Russian. However, when translating, you can easily understand the content of the sentence without doing so.

Similarly, incomplete verbs in hackneyed phrases are not reflected in the Russian translation. For example: (Агар) қийин бўлмаса. - If you don't mind. Translated into Russian language the word бўлмаса (don't) does not find its expression. In other words, in such examples, the word бўлмоқ in Russian translation in most cases is omitted. In reality, we should say: «Если тебе не будет трудно»- «If it won't be difficult for you», «Если тебе можно» - «If you сап», «Если возможно» - «If possible». But in Russian, such expressions are very rarely used. 
It should be recalled that in the Uzbek language, in such sentences as Агар (If) қийин бўлмаса (it is not difficult) in most cases, the word if (agar) is not used.

The Uzbek expression (phraseology) used as a hackneyed phrase is translated into Russian as a simple verb. For example: Қўлимдан келмайди. - I cannot. This expression is sometimes expressed in Russian in the form of a hackneyed phrases: "It is not in my power".

There are not many similar speech cliches that are a phraseological combination. In particular: Ишингиз ўнгидан келсин! - Good luck with your work! Қулоғим сизда! - I'm listening! Қаёқдан офтоб чикди? - Where did the sun come from? Қулоғига гап кирмайди. - Disobey. Йўл бўлсин? - Where are you going? (Where you (You))?

Students must memorize Uzbek phraseological units along with the Russian translation.

In some Uzbek hackneyed phrases, the question word нима in Russian is expressed by the question word "what", for example: Нима янгиликлар бор? - What news?

Such translations are observed mainly due to the presence of an interrogative word. Students should translate the word Нима as how, but they first try to Express this word in Russian in its lexical meaning (Нима янгиликлар бор? - literally: How news is there?). After realizing that the translation was unsuccessful, they correct their translation to "What news is there?"

This, the valency of the word and the syntactic connection a dialectically interconnected, mutually whole, inseparable, but at the same time, each is a relatively independent active phenomenon. [3; p. 299].

3. Hackneyed phrases in Uzbek and Russian languages sometimes differ from the grammatical side in terms of lexical correspondence. We will look at similar differences in the hackneyed phrases of both languages.

In some hackneyed phrases, Uzbek affixes of belonging, as well as personal pronouns in the nominative case (I, you, he/she/it, etc.) are transferred to Russian not by possessive pronouns (my, your, his/her/its, our, etc.), but by personal pronouns in the dative case. For example: Ёшим ўнда. - I'm ten years old. Мен нима хам дердим. - Well, what can I say. Кирсам бўладими (майлими)? - Can I come in? Ўзингиз биласиз. - You should know.

Sometimes the forms of the imperative mood of verbs are translated into Russian in the above way: Қандай қилай? - What should I do?

Russian Russian sentences that Express age, such as «Ёшим ўнда», «Мен ўн ёшдаман», literally translate the word "ёшим" to "my age", and the word "Мен" to 
"I", but as a result, the phrase will not be constructed in Russian. This is doubtful for the student who translates the sentence into Russian. To direct a student to correct translation, they should be asked what questions related to the age of the person are asked, and what answers are given in Russian. The student will certainly name such sentences as "How old are you?","I am... years old.". In such cases, the Uzbek hackneyed phrases is replaced by a distinctive hackneyed phrases, compiled in accordance with the laws of Russian grammar. This means that when explaining the content of the Uzbek hackneyed phrases and expressing it in Russian, you need to master the skill of using phrases that correspond to the speech situation.

If the translation offers «Кирсам бўладими?» Russian Russian language student will remember the word men as a subject and Express it in Russian with the word "I", then it will be difficult to deduce the correct content from such a translation. Only after he realizes that the verb "бўлади" can be translated by the word "can", he will be able to understand the phrase "кирсам бўладими" the right way: can I come in and based on this, translate the hackneyed phrases into Russian in such a form as "Can I come in?". In this case, the correct translation of the verb into Russian encourages the student to use the word "I".

It should be recalled that in textbooks of the Uzbek language intended for Russian-speaking students, the study of the form «-са бўлади» is not highlighted at the level of a separate topic. Therefore, it is advisable for the teacher to give brief information about this form, to remind students that it is characteristic of colloquial speech, that it is synonymous with the form «-(и)ш мумкин», which refers to book speech. It is useful to show it to children on the basis of examples for comparison: Кирса бўладими? (So they ask in colloquial speech) - Кириш мумкинми? (So they ask in a business speech).

In the Uzbek language in those cases where the participle with the appropriate possessive affix, leaning, understanding of these forms occurs with certain difficulties. When combined with the word «хурсандман», a participle that has an affix of the original case (- дан) forms a hackneyed phrase. This participle is translated into Russian by the indefinite form of the verb. For ехаmple: Танишганимдан хурсандман. - I'm glad to meet you.

As a rule, the participle in the original case is transmitted in Russian as a verb form with a combination of prepositions with a pronoun, such as to what; from the fact that: суюнганимдан қичқириб юбордим - I screamed because I was happy; келмаганидан хафа бўлдим - I'm offended that he didn't come. This happens when the forms are similar in both languages, but in speech cliches such as «Танишганимдан хурсандман», the initial form of the participle in Uzbek should be expressed in 
Russian by an indefinite verb form. If a student can translate the word хурсандман into Russian with the word glad, then they can easily form a hackneyed phrase by translating the verb танишмоқ with the word meet. However, they will not think about how to translate the Uzbek affix of the original case (-дан) into Russian, so they will simply skip it during translation. Such examples of translation require additional explanations from the teacher. In order to develop the necessary skills, you can ask students to translate sentences such as «Келганингдан хурсандман», «Ғалаба қилганингдан хурсандман».

When translating some hackneyed phrases into Russian, attention is drawn to the non-suffixal part of the word, i.e. the plural affixes (- лар) and the corresponding possessive affixes are omitted. For example: Ўқишларинг қалай? - How are you studying? Ишларинг яхшими? - How are you doing?

This translation is based on the function of the question word or word with an interrogative affix, i.e. on the semantics of the words қалай, яхшими - what the interlocutor asks. The words қалай, яхшими should be translated with the question word how. Knowing this, the disciple, the words ўқиш; иш automatically translates into Russian language: study; work (business), while, as a matter of course, omits the affixes available in the Uzbek version of words (-laring), i.e., bypassing them, remembers the Russian hackneyed phrases.

Personal pronouns with the - ники affix in Uzbek are translated into Russian by possessive pronouns, and sometimes by a reflexive pronoun. For example: Ўзингники-чи? - And yours?

The reflexive pronoun with the affix - ники in Russian is expressed by the word own. Such a translation may cause doubt in the student: after all, both the word «y̆з» and the word with the affix - ники are translated the same way: ўз уйи - own home, ўзи - itself/herself/themselves, ўзинг - yourself, ўзингники - yours. In such cases, to explain to the students the teacher reminds them of expression in the Russian language, the possessive affixes of the word his in such sentences as, «Мен китобимни олдим», and explains that the affix "- ники" in Russian language translated in two ways: бy меники - this is my, this is (my) own; бу сеники - it's yours, it's (your) own; бу уники - this is his (her), this is (his / her) own. The use of -ники is explained first, as an example мен ўзим - I myself (in the sense of indicating an action related to the person himself), then reflexive pronouns with the affix - ники are presented: ўзимники, ўзингники - my own, your own (in the meaning of an indication of a thing belonging to the person himself). However, most often the words "my" and "your" are omitted in speech and the meaning of these words can be expressed in one word "own". Additional information is provided to students about the possibility of this approach. 
In some hackneyed phrases, personal affixes of the Uzbek verb are expressed in Russian by possessive pronouns. For example: Соғ-саломатмисан? - How is your health?

Phrases such as «Соғ-саломатмисан?», «Тузукмисан?» on Russian language can be transmitted in two ways: "Are you healthy?", "How is your health?". The first option (Are You healthy?) it is used when you can see the deterioration of the real state - human health. In the second version of the question, the hidden subject (сен), which is indicated by the personal affix (-сан), is translated into Russian by the possessive pronoun. In fact, the question "Are You healthy?" in Uzbek corresponds to the question «Тузукмисан?», since it is asked to a person whose complexion and General appearance indicate that he is ill.

The question «Саломатмисан?» clarify the status of the health of a healthy person. This question should be expressed in Russian words health, condition.

Translating an interrogative sentence into Russian with the phrase «Are You healthy?» is convenient if the form is verbatim and grammatically similar. However, to Express this idea with questions like «How are you feeling?» and «How are you feeling?», we must remember the rules of questioning about the state of health that are typical of the Russian people. Of course, this is more difficult to implement. When the student translates the Uzbek hackneyed phrases «Саломатмисан?», уou should ask him what other questions can Express this idea in Russian.

Uzbek verbs in the present-future tense form are translated into Russian by verbs in the present tense form. For example: - Эшитаман... (present-future tense) Listening (present time).

There are a lot of such speech cliches. For example: Муваффақият тилайман. - I wish you success. Таний(яп)сизми? Хафа кўринасан? Ўзинг биласан? Овора бўласан!

In speech practice, there are also cases when the present-future tense form of the Uzbek verb is translated into Russian by both the present and future tense. For example: ўқийман - I am studying (currently), I will study (future time), ёзаман - I write (present tense), I will write (future tense), etc.

Mistakes are often made when translating a Russian verb in the present tense form into Uzbek. For example, if you translate the verb hear in this way - эшитяпман, эшитаман, эшитиб ўтирибман, that Uzbek эшитяпман in Russian, it will sound hear, when translated back: эшитаман - слушаю. The word эшитиман - hackneyed phrases. If the student says eshityapman instead of this word, the listener on the phone will immediately think that the other person is only now hearing it. 
The present-future form of the Uzbek verb is sometimes translated into Russian by the imperative mood of the verb. For example: Кечирасиз! Авф этасиз! (the present-future tense of the verb). - Sorry (imperative mood of the verb). Айбга буюрмайсиз! (the present-future tense of the verb) - Sorry. Don't take it for a fault (imperative mood of the verb).

In the Uzbek language, in some dialogical replicas, the meaning of the imperative mood of the verb of the second person is also expressed in the form of the present-future tense. For example: «Кечирасан(сиз)!». This form puts the Russianspeaking interlocutor in a difficult position, since he cannot correctly understand the content of the sentence. If you translate the sentence verbatim, in a grammatically appropriate form, then you need to remember the question in the form of the expression Sorry! But in Russian, the interlocutor is not addressed in this way. If a student is told that the word «Кечирасиз» is used instead of the word «кечиринг», they will guess that these words must be translated into Russian using the words sorry, excuse me.

Sometimes you can use a noun instead of a verb: $У_{3}$ ! Узр - the noun is in the nominative case, but it is used instead of the verb кечирасиз.

In some cases, words in both languages differ in case. For example: - Бу менга боғлиқ эмас. - It's not up to me.

Along with the fact that the case affixes of the Uzbek language have corresponding forms in Russian, there are also distinctive aspects in their use. In most cases, differences in the cases of both languages are observed in word combinations that are linked by the control method, more precisely, by verb control. If voice stamp «Бу менга боғлиқ эмас» word "боғлиқ" requires the dative of the personal pronouns "me", in Russian language the verb "depends" governs the genitive with the preposition "up to". For this reason, there are differences in the case form of the personal pronoun.

Often the possessive affix in a word that is present in the Uzbek hackneyed phrases is not reflected in the Russian translation, i.e. it is omitted. For example:

- Ишингиз ўнгидан келсин. - Good luck with your work.

4. Hackneyed phrases of the Uzbek language are transmitted to the Russian language by an analogy that has lexical and grammatical inconsistencies. For example: Хорманг. - May god speed you. Шукур. - thank God.

Hackneyed phrases «Отинг нима?», «Отим...» of the Uzbek language in Russian are expressed lexically and grammatically in a different form: «What's your name?», «My name is...». In these examples, the words "от", "нима" are translated into Russian not by the words "name" or "what", but not by the words "name" and "how". The corresponding possessive affix in the words "oting" and "otim" in Russian is expressed by personal pronouns in the genitive case without a preposition: me, you. 
In the question and answer «Отинг нима?», «Отим фалончи», possessive affixes (- im, - ing) in Russian are expressed not by possessive pronouns (my, your), but by personal pronouns in the genitive case (me, you). And in this case, you need to learn to use the Russian form of words based on the content of the hackneyed phrases. So, the student of the word form "отинг", "отим" should not translate into Russian the words "твое имя", "мое имя", he should Express this idea with the words "тебя зовут", "меня зовут". It follows that the use of the word "name" instead of the word "name" is influenced by the Russian equivalent of the hackneyed phrases.

Template words and phraseological phrases of the Uzbek language are translated into Russian using the wrong vocabulary. For example: Зўр - Great. Михдай. - on the dot (cool). Хизмат бўлмаса. - If you don't mind. During translation, students try to find the dictionary meaning of the Uzbek word. They can find the translation of a word зўр - strong, a word form михдай - like dot, verb бўлмайди - not happen, word жон - soul. Here, students should be asked to recall Russian words based on the context and speech situation. Since the word sy̆p means the meaning of delight from something, then I remember the equivalent in Russian-the word great. This means that students should come to the conclusion that in order to understand a template word-sentence or word form, it is necessary to recall hackneyed phrases expressed during similar speech situations in Russian.

In the Uzbek language, the action name is considered one of the verb forms. In Russian, there are nouns formed from verbs (verbal nouns). So, the Uzbek, the names of the actions are expressed in the Russian language nouns: сузиш - swiming, юриш - walking. Some verbs in hackneyed phrases are also translated from Uzbek into Russian by such nouns. In the hackneyed phrases «Яхши боринг», the verb " «боринг», based on the hackneyed phrases, is translated into Russian by the word trip. As you can see, the literal translation is inappropriate here. You need to remember the equivalent value of the hackneyed phrases in Russian. When translated literally, it will literally sound like this: «Яхши боринг»- «All right go». Equivalent in meaning translation: «Счастливой поездки» «Have a good trip».

5. The hackneyed phrases in Uzbek does not have an equivalent version in Russian. For example: Сўрайверинг, бемалол. - Ask (a word бемалол doesn't have a translation).

\section{CONCLUSION}

Russian Russian dictionary of hackneyed phrases is important to take into account all five similar cases related to finding an equivalent translation in Russian, as well as to provide students with an Uzbek-Russian dictionary of hackneyed phrases. 


\section{REFERENCES}

1. Лафасов У.П. (1996). Диалогик нуткда субъектив модалликнинг ифодаланиши: - Тошкент., 175 б.

2. Yo'ldoshev R.A. (2015). Ta'lim rus tilida olib boriladigan maktablarda o'zbek tilini o'qitish metodikasi: Monografiya. - Toshkent: «Fan va texnologiyalar Markazi», 157 bet.

3. Расулов Р., Абдуллаева Н. (2020) Дипломатия ва дипломатик нутқ// Filoloji ve kültür araştırmaları. - Karabük (Türkıye), 2(2), 42-45.

4. Расулов Р. (2020). Валентность слова и синтаксическая связь. Тил, таълим, таржима. Халқаро журнал, 3(1), 8-16.

5. Rasulov R. (2020). Word Valence and Syntactic Relationship. International Journal of Psychosocial Rehabilitation, 24(02), 295-300.

6. Rasulov R. (2020). Agency Valency of Voice Forms of the State Verbs (On the Material of the Uzbek Language). International Journal of Multicultural and Multireligious Understanding, 7(7), 308-317.

7. Rasulov R. (2020). Kelajak - til sohiblariniki. Til va adabiyot ta'limi, 7(7), 63-64.

8. Ботирова Ш.И. (2020). Об обучении студентов филологии основам анализа и литературным терминам. Преподавание языка и литературы, 7(7), 82-83.

9. Botirova, S. (2020). The Role of Artistic Psychology in the Metaphorical Harmony of Man And the Reality of Life. Asian Journal of Multidimensional Research, 9(4), 1620 .

10. Botirova S. I. (2020). For Students of Philology Teaching Literary Conditions of Learning Basic Analysis. Science and Education, 1(5), 110-113.

11. Botirova S. I. (2020). Problematic Aspects Related To the Use of Educational Technologies And Interactive Methods In The Classroom. International Journal of Multidisciplinary Research, 6(8), 539-541.

12. Botirova S. I. (2020). The Relationship Between Symbolically Figurative Interpretation And Psychology. Asian Journal of Multidimensional Research, 9(9), 1215 .

13. Botirova S. I. (2018). Methodology And Technology of Social And Pedagogical Activity. Теория и практика современной науки, 1(31), 14-16.

14. Botirova Sh. I. (2018). The Role of Artistic Literature In The Spiritual Development of Youth. Мировая наука, 5(14), 26-28.

15. Botirova S. I. (2019). Poetics of artistic psychologism. Теория и практика современной науки, 2(44), 31-34. 
16. Botirova S. I. (2018). Symbolic-figurative talk and psychological relations. «Экономика и социум». 12(55), 114-118.

17. Джураев А. Х. (2009). Технология совершенствования коммуникативных навыков студентов на иностранном языке (на материале синонимов испанского языка): Автореферат дисс. ... канд. филол. наук. - Ташкент, 2009. - 22 с. 